\title{
The Relation of LBW, Mother's Height with The Accidence of Stunting in the Children Among 6-24 months in Aceh Barat Regency
}

\author{
${ }^{1 *}$ Itza Mulyani, ${ }^{2}$ Marniati, ${ }^{3}$ Hanif Muchdatul Ayunda \\ ${ }^{1}$ Nutrition Departemen, Faculty of Public Health, Universitas Teuku Umar \\ ${ }^{2}$ Public Health Departement, Faculty of Public Health, Universitas Teuku Umar \\ ${ }^{3}$ Nutrition Departemen, Faculty of Public Health, Universitas Teuku Umar \\ Coresponding author: Itza Mulyani, e-mail: itzamulyani@utu.ac.id
}

\begin{abstract}
Stunting is the condition of malnutrition where the height is not as proportional as the age which can be investigated by the measurement of height indicator based on age. Stunting signifies the lack of nutrition condition which has happened for a long time and requires the time for children to grow and to be fully recovered. According to RISKESDAS 2013 report, the prevalence of stunting in children under five years is $37,2 \%$. One of the provinces which regarded as a serious category is the Province of Aceh with a prevalence of $41,5 \%$ consists of the very short $20,1 \%$ and the short around $21.4 \%$. The regency of Aceh Barat is one of the regencies in Aceh province. This regency still confronts severe nutritional issues, one of them is stunting with the prevalence of $40,9 \%$. There are many factors related to the case of stunting, for example LBW (Low body weight), mother's height. Knowing relation LBW, mother's height with the accidence of stunting in the children 6-24 months old in Aceh Barat regency. This study is an analytic observational study with the quantitative method. The design of this study is cross sectional which learn the correlation between independent variables and the dependent variables, where the measurement of both variables was conducted at the same time. From 212 children, there are 55,66\% children suffer from stunting. The result of bivariate analysis suggests that the factors related to stunting is low birth-weight $(p<0.05)$. Height of the mother are not related to stunting cases $(p>0.05)$. The factors related to stunting is low birth-weight.
\end{abstract}

ARTICLE INFORMATION

Submitted: $11 / 11 / 2020$

Revised: $23 / 11 / 2020$

Accepted: $28 / 11 / 2020$

Published Online: 30/11/2020

Keywords:

Low Birth Weight (LBW)

Mother's Height

Stunting

How to cite this article: Mulyani, I., Marniati, Ayunda, H. M. (2020). The Relation of LBW, Mother's Height with The Accidence of Stunting in the Children Among 6-24 months in Aceh Barat Regency. JNS : Journal of Nutrition Science, 1(2), 33-37.

\section{Introduction}

Stunting is a linear growth retardation with a deficit in body length of $<-2$ z-score according to the growth reference standard. Stunting describes a long-standing state of malnutrition and it takes time for children to develop and recover. Stunting can also be used as an indicator of nutrition in determining the success of improving the quality of human resources because a nutritional problem has a negative impact on the quality of life of children in achieving optimal growth and development according to their genetic potential. Stunting in children under five is $37.2 \%$ (2013), this figure shows no decrease compared to $2010(35.6 \%)$ and 2007 $(36.8 \%)$. This report states that there are 15 provinces that fall into the serious category. Serious category if the prevalence of stunting is $\geq 40 \% 8$. One province that is included in the serious category is Aceh province with a prevalence of $41.5 \%$ consisting of $20.1 \%$ very short and $21.4 \%$ short. 
West Aceh Regency is one of the districts in Aceh Province. This district still confront serious nutritional problems, one of which is stunting with a prevalence of $40.9 \% 6$ and is in 10th place out of 23 districts / cities. This figure shows that the problem of stunting is also a nutritional problem in West Aceh District.

The basic causes of stunting include the economic and political environment that underlies socioeconomic status and the direct causes are inadequate food intake and infectious diseases Khairunnas, et. All, (2020). Family socio-economy, namely education, work and income, are risk factors for stunting in children. Genetic factors, namely the height of parents have an impact on the growth rate of new children entering school. Birth weight also affects stunting. Children aged 6-24 months who were born with a history of low birth weight (LBW) were 5.6 times more likely to experience stunting than children born with normal birth weight.

\section{Method}

The research is a quantitative study with a cross sectional design. The research was conducted in four public health centers in West Aceh Regency, namely Johan Pahlawan Health Center (Johan Pahlawan District), Suak Ribee Health Center (Johan Pahlawan District), Meureubo Health Center (Meureubo District) and Meutulang Puskesmas (Panton Reuh District). The location selection was carried out by means of simple random sampling.

The population of this study were all children under five in West Aceh Regency. The samples of this study were toddlers aged 6-24 months who were selected based on inclusion and exclusion criteria. The sample size calculation is determined using the formula Lemeshow et al. (1990). Based on the calculation, the number of samples needed is 212 children.

The dependent variable in this study was stunting, the independent variables were LBW and the mother's height.

The research instrument was a microtise to measure the mother's height with an accuracy of $0.1 \mathrm{~cm}$, a lengthboard measuring device for the length of the child $<2$ years with an accuracy of $0.1 \mathrm{~cm}$ and a structured questionnaire to find out about LBW.

\section{Results}

The characteristics of subjects were obtained from univariate analysis. The number of subjects were 212 children aged 6-24 months spread over four public health centers located in three districts. From the results of the univariate analysis, it was found that the proportion of the sex of children was almost the same, namely $50.94 \%$ for girls and $49.06 \%$ for boys. Based on the results of univariate analysis, it was found that 212 children who suffered from stunting were 118 (55.66\%) and 94 (44.34\%) had normal height according to age. Most of the children born with normal body weight were $86.32 \%$ and those with low birth weight were $13.68 \%$. The proportion of the mother's height was $88.68 \%$.

Table 1. The characteristics of subjects

\begin{tabular}{lcc}
\hline Variables & $\mathrm{n}$ & $\%$ \\
\hline $\begin{array}{l}\text { Children Length } \\
\text { Stunting }\end{array}$ & 118 & 55,66 \\
$\begin{array}{l}\text { Normal } \\
\text { Gender }\end{array}$ & 94 & 44,34 \\
Girls & & \\
Boys & 108 & 50,94 \\
Birth Weight & 104 & 49,06 \\
LBW & & \\
$\begin{array}{l}\text { Normal } \\
\text { Mother's Weight } \\
\text { Short }\end{array}$ & 29 & 13,68 \\
Normal & 183 & 86,32 \\
& 24 & 11,32 \\
& 188 & 88,68
\end{tabular}

From this study, it was that children born with low birth weight had a 3.55 times greater risk of stunting than children born with normal weight with an OR $=3.55$ (95\% CI $=1.32$ 11., 11). Based on Table 2 it can also be seen that mother's height has not related with stunting $(p=0.249)$.

\section{Discussion}

The bivariate table shows that children born with low body weight and stunting are $19.49 \%$. The results of the bivariate analysis that there was a significant related between LBW and the incidence of stunting in children aged 6-24 months $(p=0.006)$. Children born with low birth weight tend to be 3.55 times more likely to stunting than children born with normal weight. Children aged 6-24 months with a history of LBW birth have a 5.6 times greater risk of stunted compared to children with a history of normal birth. Soetjingningsih 
(2012) states that there are two factors that influence infant growth, namely genetic factors and environmental factors. Genetic factors are the basis of the baby's growth process. Environmental factors determine whether the innate potential is achieved or not. There are two environmental factors, namely environmental factors that affect the baby while still in the prenatal, namely such as maternal nutrition during pregnancy, disease and hormonal infections and factors after the postnatal. Environmental factors determine whether the innate potential is achieved or not. There are two environmental factors, namely environmental factors that affect the baby while still in the prenatal, namely such as maternal nutrition during pregnancy, disease and hormonal infections and factors after the postnatal. Poor maternal nutrition before the onset of pregnancy and during pregnancy, more often than not giving birth to LBW babies.

Table 2 Cross-tabulation of the factors related to stunting

\begin{tabular}{|c|c|c|c|c|c|c|}
\hline Variables & $\begin{array}{l}\text { Stunting } \\
(\mathrm{n}=118)\end{array}$ & $\begin{array}{l}\text { Normal } \\
(n=94)\end{array}$ & $\begin{array}{c}\text { Total } \\
(\mathrm{n}=212)\end{array}$ & $\mathrm{p}$ & OR & $\begin{array}{l}\text { 95\% Conf. } \\
\text { Interval }\end{array}$ \\
\hline \multicolumn{7}{|l|}{ Birth Weight } \\
\hline LBW & $23(19,49)$ & $6(6,38)$ & $29(13,68)$ & 0,006 & 3,55 & $1,32-11,11$ \\
\hline Normal & $95(80,51)$ & $88(93,62)$ & $183(86,32)$ & & & \\
\hline \multicolumn{7}{|c|}{ Mother's Weight } \\
\hline Short & $16(13,56)$ & $8(8,51)$ & $24(11,32)$ & 0,249 & 1,69 & $0,64-4,77$ \\
\hline Normal & $102(86,44)$ & $86(91,49)$ & $188(88,68)$ & & & \\
\hline
\end{tabular}

Handling of low birth weight children and stunting can be done with specific nutritional intervention efforts for toddlers that focus on the first 1000 days of life (HPK) group, namely pregnant women, nursing mothers and children aged 0-23 months. The 1000 HPK period covering 270 days during pregnancy and the first 730 days after the baby is born has been scientifically proven to be a period that determines the quality of life. In contrast to research conducted by Ernawati et al. (2013) stated that there was not significant related between low birth weight and the incidence of stunting ( $p=0.739)$.

The bivariate analysis showed that maternal height had not statistical related to the stunting ( $p=0.249)$. It is possible that the proportion of mothers who have normal height ( $\geq 150 \mathrm{~cm}$ ) is more than half, namely $88.68 \%$. Mothers whose height $<150 \mathrm{~cm}$ tended to have a stunted child 1.69 times greater than mothers whose height was $\geq 150$ $\mathrm{cm}$. There is not correlation between maternal height and the incidence of stunting, presumably because the short mother is a result of malnutrition, not due to genetic abnormalities in chromosomes. This study did not examine any risk factors that affect maternal height so that it could not be distinguished whether the mother's height was caused by genetic, pathological or malnutrition. Short traits in parents are caused by nutritional or pathological problems, so the short trait will not be passed on to their children, on the contrary, if the short traits in parents are caused by genes in chromosomes that carry short traits, it is likely to pass on these short traits to their children. Contrast to Rahayu's (2011) study, maternal height has a significant relationship with changes in stunting status in both boys and girls. There is a tendency that maternal height has a greater risk $(\mathrm{OR}=1.9)$ in girls than in boys $(\mathrm{OR}=$ 1.5).

\section{Conclusion}

There is a related between birth weight and the stunting.

\section{Acknowledgement}

The study, it can be suggested that the provision of balanced nutrition and prevention of anemia in mothers before and during pregnancy can prevent LBW, for local governments it is expected to be successful and active in 1000 HPK activities because these activities are very important in improving the nutrition and quality of life of children who are more optimal. One thousand HPK is expected to reduce the number of anemia mothers, prevent LBW children so that it can reduce stunting rates. For further researchers, further research is needed with a cohort research design to see the relationship 
between LBW variables and the incidence of stunting.

\section{References}

Adair,L.S. \& Guilkey, D.K, 1997.Age-specific determinants of stunting in Filipino Children. The Journal of Nutrition, 127(2), pp.314-320

Allen, L.H. \& Gillespie, S.R., 2001. What Works? A Review of the Efficacy and Effectiveness of Nutrition Interventions

Amigo, H., Bustos. P., Leone. C., Radrigan, M.E. 2001. Growth deficit in Chilean school children. American Society for Nutritional Sciences, PP.251-253

Balitbangkes Kemenkes RI, 2013. Riset Kesehatan Dasar. , pp.1-306.

Balitbangkes Kemenkes RI, 2010. Riset Kesehatan Dasar.

Balitbangkes Kemenkes RI, 2007. Riset Kesehatan Dasar.

Black, R.E., Allen, L.H., Bhutta, Z.A., Caulfield, L.E., Onis, M. D., Ezzati, M., Mathers, C., Rivera, J. 2008. Maternal and child undernutrition: global and regional exposures and health consequences. The Lancet, 371(9608), pp.243-260.

Chirande, L. Charwe, D., Mbwana, H., Victor, R., Kimboka, S., Issaka, A.I., Baines, S.K., Dibley, M.J., Agho, K.E., 2015. Determinants of stunting and severe stunting among under-fives in Tanzaniz: evidence from the 2010 cross-sectional household survey. BMC pediatrics, 15, p. 165

Ernawati, F., Rosmalina, Y., Permanasari, Y. 2013. Pengaruh asupan protein ibu hamil dan panjang badan bayi lahir terhadap kejadian stunting pada anak usia 12 bulan di kabupaten Bogor. Penelitian Gizi dan Makanan, Vol. 36 (1): 1-11.

Henningham, H.B \& Mcgregor, S., 2005. in : Gibrey, M.J., Margaretts, B.M., Kearney, J.M., Arab, L., Alih bahasa: Hartono, A.
Gizi Kesehatan Masyarakat (Public Health Nutrition). Jakarta: Penerbit Buku Kedokteran EGC, PP.302-323

Khairunnas, K., Husna, A., \& Marniati, M. (2020). The Relationship of SocioEconomic with Nutritional Status in Toddlers in Meureubo Sub-District West Aceh Regency. Journal of Nutrition Science, 1(1), 6-10.

Mamabolo, R.L., Albert., M., Steyn, N.P., Waal, H.A.D., Levitt, N.S. 2005. Prevalence and determinant of stunting and overweigth 3-years-old black South of African children residing in the central region of Limpopo province, South Africa. Public Health Nutrition 8 (5): 501-508

Mushtaq, M.U., Gull, S., Khurshid., Shahid, U., Shad, M.A., Siddiqui, A.M., 2011. Prevalence and socio-demographic correlates of stunting and thinness among Pakistani primary school children. BMC public health, 11(October), p.790

Nasution, D., Nurdiati, D.S., Huriyati, E., 2014. Hubungan berat badan lahir dengan stunting pada anak usia 6-24 bulan di Kota Yogyakarta. Jurnal Gizi Klinik Indonesia. Vol.11, No.01:31-37.

Pongou, R., Ezzati, M., Salomon, J.A., 2006. Household and community sosioeconomic and evironmental determinants of child nutritional status in Cameron. BMC Public Health, 6(98), PP. 1471.

Ramli., Agho, K.E., Inder, K.J., Bowe, S.J., Jacobs, J., Dibley, M.J., 2009. Prevalence and risk factors for stunting and severe stunting among under-fives in North Maluku province of Indonesia. $B M C$ pediatrics, 9, p.64.

Soekirman. 2000. Ilmu gizi dan aplikasinya. Departemen Pendidikan Nasional. Jakarta

Soekirman. 2006. Dari Empat Sehat Lima Sempurna ke Pedoman Gizi Seimbang Dalam Siklus Kehidupan Manusia. Primamedia. Jakarta 
Soetjiningsih.2012. Tumbuh Kembang Anak. Buku Kedokteran EGC. Jakarta

Stuijvenberg, M., Nel, J., Schoeman, S.E., Plessis, L.M., Dhansay, M.A., 2015. Low Intake of Calcium and Vitamin $D$ is Associated with Stunting in 2-5-Year-Old Children from an Impoverished South African Community. European Journal of Nutrition \& Food Safety, 5(5), pp.459460.

Sudiman., 2008. Stunting atau pendek: Awal perubahan patologis atau adaptasi karena perubahan sosial ekonomi yang berkepanjangan. Media Litbang Kesehatan, 18(1), pp.33-42.

UNICEF., 2010. Penuntun Hidup Sehat. Kementerian Kesehatan Republik Indonesia. Jakarta

Wahdah, S., Juffrie, M., Huriyati, M., 2014. Faktor risiko kejadian stunting pada anak umur 6-36 bulan di wilayah pedalaman Kecamatan Silat Hulu, Kapuas Hulu, Kalimantan Barat. Jurnal Gizi Dan Dietetik Indonesia. Vol. 3, No. 2: 119130.

Worid Health Organitation (WHO)., 2006. Child growth standards: length/heightfor age, weight-for-age: Methode and Development. Geneva: Departement of Nutritional for Health and Development. 